The Map and the Text: The Geo-Literary Spatial Encounters

\title{
The Map and the Text: The Geo-Literary Spatial Encounters in Literary Theory
}

\author{
Wael M. Mustafa, PhD \\ Department of English, \\ Faculty of Arts, \\ Fayoum University, Egypt.
}

\begin{abstract}
:
Geography and literature are impressed by their respective disciplinary cultures. However, they witness the emergence of contact zones that subvert the boundaries caused by the cultural divide between these two discrete disciplines. The paper discusses five encounters emerged in the wake of the spatial turn in the 1990s: geography's literature, narrative cartography, geocriticism, geo-poetics, and eco-criticism. The "the map and the text" is a spatial trope that becomes a diegetic paradigm, a structuring agent, and a signifying element in literary theory. Therefore, the objective of this paper is to illuminate the methods, objectives, divergences and convergences of these interdisciplinary encounters.

\section{Author's Bio-Note}

Wael M. Mustafa lectures in Literary Theory at Fayoum University, Egypt. His main research interests are in postmodern literary theory; postcolonial translation studies; literary journalism; eco-criticism; spatial literary theory; and Postpostmodern literary theory. Recent publications include a book entitled The Politics of Subversion (2010).
\end{abstract}


The Map and the Text: The Geo-Literary Spatial Encounters in Literary Theory

\section{INTRODUCTION}

Geography and literature have long illuminated each other. However, the disciplines encounter each other at a distance, too much impressed by following their disciplinary cultures too closely. Interestingly, out of the clash, the geoliterary encounters witness emergence of contact zones that enable them to overcome, what Charles Snow calls, "cultural divide" (16). As a result, these encounters enlighten the hermeneutics of each discipline at moments of contact. Geographers have long viewed the literary text as of great documentary value. They emphasize plot and scenic description over form and structure of the literary work. However, these encounters attempt to illuminate various representations of space - geographically and geometrically - within the literary text. Concepts of these encounters include geography's literature (Brosseau), narrative cartography (Ryan; Coquard following from Moretti; Piatti et al.), geo-criticism (Westphal; Tally), geopoetics (White), and eco-criticism (Glotfelty; Buell).

These encounters have been developed in the wake of the 'spatial turn' manifested in humanities and social sciences since the 1990s. The spatial turn in literary theory is based on the premise that the encounters between the map and the text are "centrally and inescapably implicated in all constructions of knowledge" (Cosgrove, Mappings 7). Critics use these transdisciplinary encounters "to interpret the spatiality of human life in much the same way they have traditionally interpreted [...] the historicality and sociality of human life" (Soja 7). The symbolic significance of the images of the map and the text in representing spaces, places, and landscapes in literary theory refutes the long-held idea that space is simply décor or even that it is simply a mode of representation. The main objective of this paper is to distinguish and relate the various theoretical and critical perspectives of the geo-literary encounters that map out space in literary text. 
The Map and the Text: The Geo-Literary Spatial Encounters

\section{DISCUSSION}

Newer representations of space in literary texts have led to a convergence of literature and geography and crystallised the nature and functions of geo-literary encounters. These encounters represent the spatial turn in literary theory par excellence. The intersection of literature and geography can be traced back to antiquity, as Homer is believed to be the first geographer. His work "includes a wealth of important geographico-historical knowledge, occasionally elaborated for poetic purposes" (Kim 60). Geographers' interest in literature has been in vogue since the 1970s and 1980s with the emergence of humanistic geography. The humanistic geographers, working through the lens of phenomenology, propose more thematic and impressionistic reflections on both real and fictional spaces. They seek to "understand how geographical activities and phenomena reveal the quality of human awareness" (Tuan, "Humanistic Geography" 267). They also shift the focus from the conceptual "space" to the concrete factual "place" of direct experience. Tuan stresses that the humanistic geographer "seeks meaning in the landscape, as he would in literature, because it is a repository of human striving" (“Geography" 184).

Cultural geography, in turn, investigates the cognitive, semantic, and symbolic features of perceptions and representations of space and territory. Cultural geographers concern themselves with the various literary genres as part of their socio-spatial concerns. Unlike humanist geographers, they no longer consider the literary text a mere witness of a place and landscape but rather find it an active and dynamic agent and even a mode of living. Thus, cultural geographers seek to deconstruct the ideological and cultural content of the literary text. According to Cosgrove, they explore "the meanings of place and human experience, of dwelling, attachment and rootedness" (Geography 47). Moreover, they give context significance to the 
literary form, with its many heuristic possibilities along with its formal constraints.

Literary writers, in turn, may depict real locations and places about which they retain vivid memories. They sometimes give rein to their imagination to construct fictional places and landscapes. Literary theorists attempt to deconstruct and to analyse from other critical perspectives the content of referential and fictional places in literary texts. They do not demonstrate the geographical correctness of depicted places. Rather, they show how these places and landscapes function in the plot and whether they may contain symbolic significance.

The tension residing in these geo-literary encounters becomes palpable when the two parties of these encounters do not serve a common cause. Further, they do not have the same symbolic value that endows those real or imaginary spaces and territories. During the 1970s and 1980s, the tension of these encounters reached its climax, with both disciplines coming into breach due to the disciplinary tendencies of literary theorists. Literary theorists tend to narrow the spatial analysis down to thematic and structuralist perspectives in the literary text. However, the geo-literary encounters have become more varied without abandoning the examination of spatial representations in literature. They promote a poetics in which "human spaces and literature have become inseparable, and so also have the real and the imaginary." They explore the role of interaction between imaginary and real spaces in determining cultural identities (Westphal 156).

This paper thus attempts to answer the question of whether the geo-literary encounters have created strategies and tools for the two disciplines to approach the world fully and reflect the spatial experience and the sense of belonging to a place. This paper assumes that these encounters reinforce the interactions between the two modes of apprehending reality. Although geography and literature are two distinct disciplines, they offer 
The Map and the Text: The Geo-Literary Spatial Encounters

complementary perspectives that can add significance to the complex and dynamic human relationship with space, place, landscape, and the overall geographical condition.

\section{THE GEO-LITERARY ENCOUNTERS OF LITERARY SPACE}

\subsection{Geography's Literature}

Various geographers explore the relationship between literature and geography to draw out the type of encounter at which literary and geographical topographies intersect. For the geographer Yi-Fu Tuan, literature frames concrete experience, which "is made up of innumerable perceptions, acts, and environmental impingements" ("Literature and Geography" 196). The geographer, Tuan argues, makes use of literature in "three principal ways": as thought experiment, as artefact, and as an ambitious attempt. First, literature provides the geographer with the social space; second, it illuminates environmental perceptions and cultural values; third, it provides geographers with a model for achieving a synthesis of the subjective and the objective ("Literature and Geography" 205). In the same vein, the geographer Douglas Pocock argues for the universality of literature that constitutes the "raison d'être for the geographer's engagement with literature" (12). For Pocock, literature is "distinguished by being the work of imagination rather than observation, creation rather than recording, fiction rather than fact" (10). Pocock proceeds to assert that the paradox of literature lies in the fact that its fictive reality "may transcend or contain more truth than the physical or everyday reality" (11). Pocock considers how the geographer's study of 'place' in literary texts "varies along a continuum between landscape depiction and human condition" (12). Therefore, the intersection between geography and literature can "produce an entirely new approach to meaning" (Bordessa 273).

Marc Brosseau, a cultural geographer, proposes a critical and comprehensive encounter that he calls "Geography's 
Literature," through which literature intersects with "the broader intellectual agenda" of geography ("Geography's Literature" 335). Brosseau not only documents the intersection between geography and literature but also argues that literature can be a new object for geography to examine. He criticises geographers who confine their main task to determine the geographical value of the literary texts and "whether or not they 'stick' to the kind of facts one expects to find in a geography textbook" "Geography's Literature" 337). Brosseau emphasises that geographers should search for "what might be disruptive, subversive or a source of new questions in the novel" ("Geography's Literature" 347). He explains that geographers have initially used a corpus of realistic and naturalist novels, travel narratives and urban novels in "assessing the documentary qualities of the novel" ("Geography's Literature" 336).

The emergence of humanistic geography of the phenomenological type has witnessed a shift in scope from space to place with all the themes of "[v]alues, representations, intentions, subjectivity, identity, rootedness, experience, perception [...] brought forth to make the human perspective the centre of attention" (Brosseau, "Geography's Literature" 337). To understand this shift, it is important to distinguish between the notions of space and place in literary theory. Some scholars briefly state that place is "space to which meaning has been ascribed" (Carter et al xii). Thus, the literary geography encounter highlights the spatial vectors through which "the literary text may constitute a 'geographer' in its own right as it generates norms, particular modes of readability, that produce a particular kind of geography" (Brosseau, "Geography's Literature" 349). The significance of this encounter lies in its focus on "the text itself" rather than on its author. Thus, it approximates the way the text "defines its reader, how it creates an 'eye', and how it questions geography's rational discursivity" (Brosseau, "Geography's Literature" 347). Hence, Brosseau uses 
The Map and the Text: The Geo-Literary Spatial Encounters

his concept of "novel-geographers" ("Des romans-geographes") to map out people's spatial experience within the discursive text of the novel with its "epistemological insight" ("Literature" 214). In short, this encounter investigates the novelistic spatial discourse in a way that shows how the novel is constructed as a geographical map that identifies "people and place, society and space" (Brosseau, "Geography's Literature" 348). Furthermore, it draws attention to the cultural turn in geography and enables cultural geographers to map out "the ways in which not only class and gender, but also race, ethnicity, national identity, and sexuality inform literary representation of peoples and places" (Brosseau, "Literature" 216).

\subsection{Narrative Cartography}

The geo-literary encounters draw the attention not only of cultural and humanist geographers but also of literary theorists. As the geographers design "Geography's Literature" to suit their targets, literary theorists, in turn, devise narrative cartography with different nature and functions. Through this encounter, literary theorists map out "complex overlays of real and fictional geographies" in literary genres (Piatti and Hurni 218). Moreover, as Franco Moretti states, narrative cartography "shapes the narrative structure of the European novel" (8). Piatti and Hurni explains that this encounter comprises two distinct but interrelated fields of geographical studies: the geography of literature and the cartography of literature. For Piatti and Hurni, the latter "can be looked upon as a sub-discipline or an ancillary science" of the former (Piatti and Hurni 218). Moreover, Piatti and her fellow researchers state that "literary cartography provides one possible method, more precisely: tools in order to explore and analyse the particular geography of literature" (Piatti and Hurni 218). Moretti and Piatti are aware of the criticisms stemming from their inevitably reductive and fragmentary method. Piatti and her co-authors refute these accusations by stating that the use of abstraction and statistical methods "has to 
be imagined as a rather complex interplay between text hermeneutics and cartographic rendering" (Piatti et al 191). For these researchers, a hermeneutic work, both comparative and contextualising, seeks to find answers to the questions raised by the maps. Moretti points out that the work of a geographer of literature does not end with mapping a literary phenomenon; rather, "it's the beginning" of "the most challenging part of the whole enterprise: one looks at the map, and thinks" (7).

The projects of Moretti and Piatti are simultaneously congruent with literary history, as they are both comparative and historical. Drawing on a large corpus of texts from different periods and spaces, these two theorists create an inventory of cartographic analysis of the spaces, places, and landscapes projected in the literary text. This inventory represents various categories of fictional space on a set of maps. For Moretti, geography is not "an inert container or box where cultural history "happens"; but "an active force that pervades the literary field and shapes it in depth" (3). According to Moretti, two types of spaces may overlap in literary texts: the fictional and the real. The fictional space reveals "space in the literature" while the real space shows "literature in space." Moretti identifies the imaginative geographies of novels including places, borders, movements as well as "the internal logic of narrative: the semiotic domain around which a plot coalesces and selforganises" (5).

Moretti believes that narrative cartography concerns three distinct spatial indicators in literary theory. First, it provides a thorough terminology and distinct categories that let literary theorists examine "the interplay of narrative and 'real' spaces" (Tally 100). This interplay includes a large amount of information in a set of maps about places, routes, encounters, degree of referentiality, and functions and qualities of the spaces represented in novels or other literary forms. Second, Moretti demarcates the presence of the literary canon in the catalogues of 
The Map and the Text: The Geo-Literary Spatial Encounters

the "provincial libraries of Victorian Britain" (3) and any local, regional, or national geographical place that witnesses the production, the publication, and the reception of the literary text. Finally, he creates a new space for reading individual texts through "the systematic use of maps" or diagrams as analytical and intellectual tools for reading distinct elements of a literary text. According to Moretti, these maps bring "to light relations that would otherwise remain hidden" (3). By the virtue of narrative cartography, the map becomes a good critical tool for the reader to analyse the plot, to highlight the spatial nature, and to "light the internal logic of narrative" in the literary text (Moretti 5). Moreover, maps can produce "further array of interpretive paths: towards a text, a critical idea, a historical thesis" (Moretti 8).

Moretti identifies three levels for this project of mapping the literary text. The first level is a reading strategy of individual literary texts through which he plots or schematises the courses of these texts on actual maps. According to Tally, this reading strategy "becomes a supplemental interpretative method in addition to the process of interpreting the words on the page" (101). At the second level, Moretti proposes a geo-historical literary theory in which literary spaces play a vital role. Literary history should dedicate itself to the study of "horizontal' divisions among different places" as well as different social groups that are "vertically" divided." Hence, it has to "reflect on the many spaces of literary history-provinces, nation, continent, planet ... - and on - the hierarchy that binds them together" (Moretti 143-144). At the third level, Moretti establishes the narrative cartography as a theory of literary criticism that may be able to actively "recognise in the geographical variation and dispersal of forms the power of the centre over an enormous periphery" (195).

Barbara Piatti enlarges the scope and the perspective of narrative cartography. She seeks to foreground the setting or the 
location of the fictional action in her attempt to rewrite the history of literature. She offers literary atlas for the literary text by demarcating various literary settings. The maps of the literary text show concrete places, imprecisely-localised places, transformed or dislocated places, journeys and movements through space, and shifts and changes of political borders. In addition, the maps highlight projected spaces, such as dreamt-of places, yearned-for places, and places remembered by the characters. According to Piatti and Hurni, literature constructs places and spaces that "range from the realistically rendered, highly recognisable to the completely imaginary" (Piatti and Hurni 218). Piatti and her fellow researchers, thus, presuppose a referential relationship between fiction and reality. She distinguishes two types of spaces: the fictional (textual space) and the real (geospace). According to Piatti, the textual space of fiction "can feature references towards the geospace" (Piatti et al 184). Tally elucidates how readers and writers locate the setting of the literary text in the real world. Readers tend to "bring the 'real' places of a city directly into line with the 'imaginary' world they explored in their readings" (52). The setting can be in the real world or in an entirely new world with imaginary locations. However, readers do not establish any mimetic connection between the textual space and the geospace. Writers of literature, in turn, create or invent parallel textual space that can be linked to the geospace or may have roots in it. The boundary between the two worlds is permeable, allowing an exchange in both directions. In this sense, the narrative space constitutes a contact zone or an in-between space in which the textual space overlaps with, surpasses, reduces, and sometimes meets the geospace. Piatti and Hurni, therefore, states that in this contact zone, "one can find various degrees of transformed settings, spaces and places in fiction which are still linked to an existing geospatial section but are alienated by using literary 
The Map and the Text: The Geo-Literary Spatial Encounters

means such as re-naming, re-modelling or overlaying" (Piatti and Hurni 219).

In mapping the narrative spaces of literary texts, Piatti and her fellow researchers identify five main categories - which characterise this geo-literary encounter - to one of which "every topographical or geographical notion within the narrative belongs" (Piatti et al 185). These categories are designed in a way that the spatial structure of the literary text is divided into single elements with certain functions. Piatti and her fellow researchers consider this process a "process of translation" in which "one set of symbols - text - is translated to another set of symbols - map symbols" (Piatti et al 185). The first category provides map-readers with information about "setting" where the action takes place - for example, whether it is a house or a village. The "zone of action" is the second category in which several settings are combined, such as those of a whole city or a region. This category, in fact, enables readers of the literary map to identify the contact zones at which "real and fictional space overlap" (Piatti et al 179). The third category provides readers with the "projected space" at which a character is neither present nor acting; but he or she thinks of, remembers, is longing for, or imagines the spaces (Piatti et al 185). The fourth category indicates that the literary map has a topographical "marker" that are used to give names for the places in the literary texts. These names have no role in the narrative action, but they are mentioned to draw the attention of the reader. The last category demarcates the dynamic element within the narrative space, the "route" along which characters' journeys and movements are shown (185).

By identifying the complex interplay and overlapping of the cartographic map and literary text, Piatti and her co-authors achieve two goals: first, elucidating the intersection between the map and the text and hence the narrative and complex spatial structure of literary texts are clearly identified and shown on a 
map; second, offering an interdisciplinary project with clear-cut elements. This new approach, which she calls the "Literary Atlas," offers a spatial history of literary heritage "which does not stop at national or linguistic borders" (Piatti et al 193-94).

\subsection{Geo-Criticism}

Geo-criticism focuses on the study of the geographical space in literary texts. It has widely contributed to the spatial turn in literary theory. It initiated "a theoretical framework that informs various modes of textual analysis and foregrounds the significance of geography to culture without privileging any particular textual form" (Mitchell and Stadler 54). The two prominent figures who initiate this encounter are the literary critics Bertrand Westphal and Robert Tally. Westphal attributes the spatial turn in literary theory to the fact that after the Second World War, the intelligentsia lost faith in history as a progressive force; thus, he states that the "concept of temporality" has "lost much of its legitimacy," and hence has made possible "the valorising rereading of space" (Tally 12; Westphal 14, 25). The geo-critical encounter aligns with Piatti's point of view that reality and fiction are not mutually exclusive. Westphal affirms that the boundaries between the "real" and the "imagined" spaces are unstable and ambiguous in a way that the lines dividing them are crossed and re-crossed. This creates a sense of transgression in which "the distinction between reality and fiction becomes blurred" (Westphal 89). Literary postmodernism offered a new de-realised version of reality and "literature is perhaps the best option for reading this new world, by virtue of its very fictionality" (Westphal 90). Westphal argues that the new spatiality inherent in our postmodern condition is expressed in the spatial metaphors of temporality (spatiotemporality), in the mobility of space (transgressivity) and in the close connection between the world and the text (referentiality).

The geo-critical encounter endorses the principle of geocentricity over the ego-centred logic of most spatial studies. The 
The Map and the Text: The Geo-Literary Spatial Encounters

principle of geo-centricity calls for a movement "from the writer to the place, not the other way around, using complex chronology and diverse points of view" (Westphal 113). It stands against the logic that serves "the discourse on the writer, who becomes the ultimate object of critical attention" (Westphal 111). Therefore, the geo-critical encounter does not revolve around an author or a historical epoch but focuses on a specific space, whether it be a region, a city, an island, a river, or a mountain. These categories do not necessarily refer to designated spaces, but they can be perceived as thresholds, which themselves involve "a limes, or boundary line, intended to make one stop" and "a limen, or porous border, intended to be crossed" (Westphal 42). Thus, geocritics consider space geo-centrically as the primary object of analysis.

Westphal postulates four key premises for geo-criticism: multifocalisation, polysensoriality, stratigraphy, and intertextuality. Through these premises, geo-critics examine the interplay of human and literary spaces and analyse and synthesise the diverse points of view that establish the literary space. Multifocalisation "involves the confrontation of several optics that correct, nourish, and mutually enrich each other" (Westphal 113). It involves examining the literary text with all its heterogeneous textual and contextual perspectives, "which all converge in a given place, the primum mobile of the analysis" (Westphal 122). The multifocalised spatial apprehension in the geo-critical encounter is characterised by three main perspectives: "endogenous, exogenous, or allogeneous" (Westphal 128). The endogenous perspective resists any sense of exoticism as it offers a familiar native point of view of represented spaces and places. It represents the insider's point of view. The exogenous perspective, on the contrary, highlights the exotic representation of spaces, places, and landscapes from the point of view of the traveller, a foreign outsider. The allogeneous perspective, in turn, occupies a liminal space between the other 
two. It offers a hybridised spatial point of view of a familiar/habituated outsider. The exogenous perspective is widely manipulated in travel literature. Westphal does not grant privilege for any of these perspectives. Rather, Westphal argues that any attempt for defining or experiencing place should draw the attention to the "the play of their interactions" (Westphal 129). This interplay lays bare the multivalent and heterogeneous outlook on place with its richness and complexity.

Geo-criticism promotes "sensuous geography" through which the concrete or realised places in a literary text are interpreted. Westphal argues that the critical reading of spatial narrative involves a haptic, olfactory, auditory, visual, and gustatory approach for perceiving and apprehending places. The sensuous reading experience provides the geo-critic with interpretative tools for better interpretation of the places constructed by the writer or a character in a literary text. For Westphal, the sensory perception of literary spaces reflects the perspective of the writer or the character. It is also "meant to combat the visual bias of many studies of place, reminding would-be geocritics to be open to the auditory, olfactory, and tactile dimensions of place" (Prieto 25). In short, polysensoriality leads to the examination of the perceptions represented in the text and aims to go beyond the visual dimension, which often forms the sole focus of attention.

Geo-criticism entails a stratigraphic reading of places in question. A stratigraphic reading can render an analysis of a certain place over time. This premise is based on the idea that the representation of places in literary texts can have certain spatial symbolic connotations and various interpretations that evolve diachronically. So, the description of a given place should encompass all layers of symbols and signifieds accumulated at different moments of its history to lay bare the deep spatial significance of the literary text. The spatial stratigraphic not only encompasses the "representation" of a given place but its "re- 
The Map and the Text: The Geo-Literary Spatial Encounters

presentation" at various historical moments. In this respect, Westphal argues that "it is the re-presentation occurring a second time that aesthetically captures something that already exists" (Westphal 122). Stratigraphic reading is concerned with elaborating the different successive or simultaneous temporal layers in the elaboration of a place, or even a scrutiny of the different conceptions of the time elaborated by the cultural communities.

Robert Tally enriches this encounter by introducing a new field of study - "spatial literary studies" (Tally; Tally and Battista ix). For Tally, the "spatial turn" "has occasioned a remarkable expansion in the number and quality of critical works on space, place, and mapping with respect to literature" (Tally 112). Tally seeks to provide a broader sense of this encounter than Westphal does. Tally states that his conception "is broadly understood to include both aesthetics and politics, as elements in a constellation of interdisciplinary methods designed to gain a comprehensive and nuanced understanding of the ever-changing spatial relations" (113). Unlike Westphal, Tally does not provide any analysis of the literary representation of a specific space. Rather, he proposes to develop new theoretical and critical inquiry to understand "the ways that writers map their world and readers engage with such literary maps" (144).

Jameson's concept of "cognitive mapping" has obsessed Tally. For Tally, it is a postmodern practice that "refers to an individual subject's attempt to orientate his or her position within a complex social organisation or spatial milieu". In other words, it is an individual subjective production of "place in relation to various other places on a mental map" (Tally 68). On the other hand, it is not solely confined to the subjective sense of place, but to the "objective" production of space" in the postmodern global world-system (Tally 68). Tally's main pursuit is to mould cognitive mapping in literary context. Such a cognitive mapping critically comprises both writers and readers in the production of 
real and imagined spaces in literary texts. The writers map out social spaces of their world through literature and literary theory and rearrange them through the poetic expression, to infuse a meaning to them. The readers, in turn, read the fictional maps deployed by the author, using the process of cognitive mapping and spatial theories to analyse the production of space in the literary work. In brief, the geo-critical encounter offers a way of understanding literature and of conceiving and interpreting it as a fictional space. It critically proposes a method of analysis of texts centred on the question of human space and on the literary rather than the geographical. It introduces itself as a new critical way of interpreting the literary text.

\subsection{Geo-Poetics}

Literary interest in environmental issues and ecological balance has increased since the 1990s. Although environment is not synonymous with space, the two intersect through their intimate relationship with humanity. This encounter, thus, seeks to reconcile the poetics of place with the logic of human mind suggesting a dialogic discourse that literarily maps the geographical place in which humans are in a dynamic contact with their environment through mind. Geo-poetics and ecocriticism have their distinctive places as unique geo-literary encounters of spatial representation in literary narrative. By their transdisciplinary nature, the two theories go beyond most literary criticism by integrating humanities with natural sciences.

Kenneth White, the Scottish poet, established this geopoetic encounter, founding the International Institute of Geopoetics in 1989. According to White, geo-poetics is a transdisciplinary study that combines theory and practice or research and creation. He rethinks a creative space of 'cultural renewal' through which the fundamental "Humanity-Earth relationship" can be "well documented on the ecological, psychological and intellectual plane." Thus, he points out that the geo-poetic encounter "presents new existential perspectives 
The Map and the Text: The Geo-Literary Spatial Encounters

in an open world" ("Geopoetics"; emphasis added). The idea of the "open world" indicates that White is in search of a space that is free of all historical, ideological, political, or economic limitations imposed on earth by the limited view of our human mind. By so doing, White establishes this encounter as a study that is "concerned, fundamentally, with a relationship to the earth and with the opening of a world" (The Wanderer 234). Thus, geo-poets are wanderers who initiate "the continuous process of world-opening in relation to earth" (Smith 188). This process is endless and indeterminate creating a sense of free play of meanings. White calls this process "textonique de la Terre" (textonics of the earth) that "opens the human spirit to the ongoing, century-long transformations through which our planet continues to acquire new meanings" (Konończuk 153-154). Therefore, the Earth becomes a dynamic text loaded with everbecoming new meanings that evoke the eternal dialogue between the human mind and the landscape. For the absolutist White, textonics is a "style of writing" that "opens the 'text' up to the Earth/World" (On the Atlantic Edge 19). Textonics is "a textual form that is analogous to the irregular, chaotic and complex processes that shape physical space" (Riquet 11). The textonic world-opening poetics is, thus, an antidote of the absolutist textualist discourse that seeks to textualise the earth/world. On the contrary, textonics implies "new wording, new working, new worlding" (The Wanderer: 247).

The geo-poetic "open world poetics", thus, lends itself into a sense of mental geography or mental cartography that charts the landscape of thought onto Earth's text or map. This textual map of the Earth is drawn according to "territories" not "regions." According to White, the word "region" is politically invested to the extent that it connotes "identity ideology" instead of "a field of creative energy" (On the Atlantic Edge, 59). This thinking in terms of regionalism can hinder the pursuit of the original landscape of thought that is free and open that White 
favours. White prefers fluidity. Bouvet and Posthumus chart the geo-poetic sense of a territory as "a space where each individual can breathe fully, grow and establish harmonious relationships with others on the basis of a shared community and project" (394).

By questioning the relationship between man and the earth, the geo-poets open their senses and intellect to the experience of life on Earth to produce a sense of their presence in the world. Unlike the Romantics, who sought transcendence in Nature, the geo-poets seek to open a place of exchange or a contact zone of a common interest between Earth and human mind. Geo-poetics, according to White, "with analytical work and synthesis", attempts to open "a new way of thinking, a great world poem, liveable by everyone" (McManus 196). The open world poetics entails intellectual nomadism as a topographical and textual metaphor. According to White, the geo-poet is an intellectual nomad moving "across territories in order both to rid the self of habit, encumbrance, and renew contact with the earth, and explore cultures, looking for elements that might inspire and configure a new culture" (Ideas 204). The great field of geopoetics, emerged from intellectual nomadism, not only involves a long spatial, physical and geographical work, but also mental and reflexive one.

The intellectual nomad challenges monolithic discourses. For White, "The intellectual nomad who quits the monolinear, monocultural, monomaniac Motorway will pass through as many cultures as possible" (The Wanderer 246). The intellectual nomad has heterogeneous nature in crossing both territories and cultures "following a multiple itinerary, opening up uncharted space"; such a nomad "carries no flag, is the spokesman of no identity-group, incorporates no local socio-cultural context" (Ideas 204). Hence, geopoetics focuses on "the individual in isolation, the thinker in search of knowledge," to re-open a space of life and give breath to the community (Ideas 17). 
The Map and the Text: The Geo-Literary Spatial Encounters

The geo-poet seeks to create a triangular space of interconnectedness between land, mind, and language. As White points out, this encounter combines "landscape (the physical nature of the planet), mindscape (the configuration and dynamics of thought) and wordscape (a sense of language that goes away out beyond standardised communication)" (Dósa 275). This indicates that the geo-poet, as an intellectual nomad, simultaneously treads physical, mental, and linguistic paths. The geo-poet is a scout with a landscape, a thinker with a mindscape, and a poet with a wordscape. In brief, the geo-poetic encounter, through research and creation, creates new concepts as well as new ways of doing and thinking by exploring both the outside world and the world of ideas and developing a sensible relationship to the earth.

\subsection{Ecocriticism:}

In contrast to geo-poetics, with its focus on poetics and sensitivity, the ecocritical encounter is an analytical tool and a recent approach to cultural analysis. It first emerged in the United States and England in the 1990s. Eco-criticism combines both ecology, a branch of biology, and environmentalism, a social movement that has arisen from judgments about certain human practices in modern-day society. Etymologically, the word "ecology" consists of the prefix oikos (house, habitat, or dwelling) and the suffix logos (logic, language, thought). It is a scientific discipline stemming from both biology and geography. Nevertheless, it remains the study of "the relationships between living organisms in their natural environment as well as their relationships with that environment" (Tošić 44).

The eco-critical encounter can be traced back to the year 1962 when the marine biologist Rachel Carson published her Silent Spring. In this book, Carson interwove hybrid writing that mingled scientific arguments with a narrative style by using literary stylistic devices to depict the petrifying silence that for some time populated the springs of America. By setting the 
narrative in terms of "a fable for the future," Carson sought to reveal "the truth behind each of the fictional threats with scientific evidence and testimony" (Eilers 17, 18). Thus, the ecocritical encounter has been developed as "crossdisciplinary conversations" (Buell, The Future: 5). The birth of literary ecology is attributable to the American environment in the wake of new hermeneutical horizons that arose in opposition to Anglo-American New Criticism, with its belief in the ontological status of the text. Although the "environmental turn" in literary theory has arrived with a certain delay, the environmental discourse has always been "one with very ancient roots" (Buell, The Future: 2). In 1972, Joseph Meeker introduced the term "literary ecology" as "an attempt to discover what roles have been played by literature in the ecology of the human species" (9). This interdisciplinarity of literary ecology cannot remain in the shadows for the persistent reference to the extraliterary aspect, reiterated by that link between text and environment. Thus, in 1978, William Rueckert was the first critic to coin the term ecocriticism "to develop an ecological poetics by applying ecological concepts to reading, teaching, and writing about literature" (73). Therefore, the eco-critical encounter offers two-fold function of offering critical judgment (kritis) on the dwelling-house of man (oikos). Alfred K. Siewers defined this encounter as "a field of criticism that emerges in the late twentieth century as a slightly delayed response in the humanities to the global emergence of the environmental movement in the 1960s and 1970s" (205).

After a period of stalemate, the eco-critical encounter was established on the scene of Anglo-Saxon literary criticism. In 1996, Cheryll Glotfelty and Harold Fromm published their seminal text The Ecocriticism Reader, which accommodates the major figures who have initiated the scene of this encounter. In introducing the book, Glotfelty refers to "the absence of any sign of an environmental perspective in contemporary literary studies" 
The Map and the Text: The Geo-Literary Spatial Encounters

(xv). This work attempts to give a new light to the concept of "nature" by freeing it from the burdens of its oppressive origins and rendering a new concept, that of "environment." Glotfelty defines eco-criticism as "the study of the relationships between literature and the physical environment" (xviii). Through an ecocentred or "earth-centred" perspective of literary analysis, Glotfelty hopes that the eco-critical encounter can open new interdisciplinary and transdisciplinary contours that constitute a source of cross-fertilisation.

The eco-critical encounter reconsiders the notion of "nature" to comprise "environment", without prejudice to the constant relationship between the narrated world and experience. Thus, this encounter deals with literary texts as eco-texts that have a discursive environment capable of reproducing "sociohistorical environments in stylised form" (Buell, The Future 44). According to Lawrence Buell, the active relationship with reality is reduced not only to a question of factual truthfulness but to a real process of re-coding the world, incorporated by the literary work in its texture as an intrinsic and immanent subtext (The Future 44).

To show the mutual tension between the human mind and the physical environment, Buell introduces his concept of "environmental unconscious". $\mathrm{He}$ conceives it as a "mental/textual practice of foreshortening" the role played by environment through our articulations and awareness (Writing 22). In other words, people are environmentally unconscious because of their "habitually foreshortened environmental perception" (Writing 18). Buell explains that the environmental unconscious is at work when the manifestations of the physical environment are occluded in our consciousness because of "scientific ignorance, inattention, specialised intellectual curiosity, ethnocentricity, self-protectiveness, the conventions of language itself" (Writing 22). Moreover, Buell identifies the negative and the positive aspects of environmental unconscious. 
Negatively, it is impossible for individual or collective perception to come to "full consciousness at whatever level: observation, thought, articulation, and so forth" (Writing 22). Positively, the term entails "simultaneous processes of environmental awakening - retrievals of physical environment from dormancy to salience-and of distortion, repression, forgetting, inattention" (Writing 22). However, the environmental unconscious, "in both its occluding and its enabling aspects" (Writing 24), is operative in literary texts to resist any sense of closure in environmental perception and representation.

Eco-critics have identified three waves in eco-critical theory. Buell proposes the first two waves. The First wave distances itself from ecocriticism avant la lettre by entertaining a link with natural science, seeking to show the compromise between two opposing epistemological domains. According to Buell, the first wave of eco-criticism seeks "to presuppose a bedrock 'human' condition, to commend the scientific method's ability to describe natural laws, and to look to science as a corrective to critical subjectivism and cultural relativism" (The Future 18). This wave is an eco-centric or nature-oriented wave that is "self-consciously devoted to resisting anthropocentrism, sometimes to the point of wholly eliminating human figures from its imagined worlds" (The Future 100). It comprises an organic impulse and a profound correspondence between the text and the natural environment.

The second wave, in turn, has revised the first-wave tenets to "accommodate the claims of environmental justice" (The Future 22). It recognises an anthropocentric trace in nature writings by exposes crimes of eco-injustice against marginal groups within the society. In this respect, Buell points out that second-wave eco-critics are interested in "locating vestiges of nature within cities and/or exposing crimes of eco-injustice against society's marginal groups" (The Future 24). This paradoxically results in a shift in focus from non-human 
The Map and the Text: The Geo-Literary Spatial Encounters

wilderness to urban or artificially constructed places. While the second-wave writers eliminate anything that is natural, they are still devoted environmental writers. The second-wave eco-critics do not confine themselves only to nature writings and consider all types of literary texts. This entails a concept of nature no longer equivalent to the concept of environment. The eco-critics of this wave have addressed both human and non-human issues, urban and suburban environments as well as wilderness landscape. In this respect, Donna Haraway precisely points out that symbolically "nature and culture, as well as sex and gender, mutually (but not equally) construct each other; one pole of a dualism cannot exist without the other" (12). This creates a dialogic context of humans and their environment. Therefore, the difference between the first and second waves of the eco-critical encounter concerns the very concept of environment. The first wave adheres to biocentric, eco-centric, and nature-oriented paradigms, and the second wave endorses a socio-centric paradigm.

The third eco-critical wave explores "all facets of human experience from an environmental viewpoint" (Adamson and Slovic 7). It takes on an expansion and deepening of ethnic and national issues. It "recognises ethnic and national particularities and yet transcends ethnic and national boundaries" (Adamson and Slovic 6). For Slovic, this wave operates according to multiple interpretive guidelines and multi-disciplinary vectors. On the one hand, the concept of "place" can be re-read in the light of bioregionalism (Berg). Pressures lead to "questions about the possibility of a post-national and post-ethnic visions of the human experience of the environment" (Slovic 7).

In brief, ecocriticism has contributed to the transdisciplinary geo-literary encounter by promoting dialogue among literary studies, sciences, humanities, ethics and ecological thinking in a context of environmental crisis caused by human actions in ecosystems. The encounter seeks to bring 
together environmental issues study with literary studies and to open critical horizons that blur the barriers between the outside and the inside of the texts.

\section{RECAPITULATION}

To sum up, the literary text constitutes an object for the geographer just as geography contributes to creating an innovative lens through which a new reading of this text becomes possible. The literary text and the geographical map intersect in a way that the meaning of a place becomes a reference for the readers. This paper has elucidated various referential or metaphorical representations of the geo-literary encounters in the literary text to highlight the different objectives, methods, divergences and convergences of these representations. These encounters assume that literature is in some way related to reality. Thus, notions of referentiality and performativity have returned to the literary field after a formalistic and structuralist period. The boundary between the fictional and the real worlds is permeable, allowing "a bidirectional exchange." The fictional world implies that "the poetic imagination works with 'material' drawn from actuality"; however, "our imaging and understanding of reality" depends heavily on the fictional world (Doležel x). This challenges the "segregationist" view with its impermeable border between fictional and actual worlds (Pavel 11). Such a view deprives "literature of any ethical, existential, political or didactic value" (Ryan 729).

Geo-literary encounters lend a map to the text to penetrate the immateriality of the geographical tension that partly animates literary creation as well as to deconstruct the symbolic references of space, place, and landscape. The geographers and literary theorists frame these to lay bare the complex and polymorphic nature of the interplay in the literary representations of real and imagined places. In so doing, the geo-literary encounters demarcate the symbolic, territorial, and identity issues related to spatial poetics. 
The Map and the Text: The Geo-Literary Spatial Encounters

WORKS CITED

Adamson, Joni, and Scott Slovic. "Guest Editors' Introduction: The Shoulders We Stand On: An Introduction to Ethnicity and Ecocriticism." MELUS: Multi-Ethnic Literature of the U.S., vol. 34, no. 2, 2009, pp. 5-24., doi:10.1353/mel.0.0019.

Berg, Peter. The Biosphere and the Bioregion: Essential Writings, edited by Cheryll Glotfelty and Eve Quesnel, Routledge Environmental Humanities Series, London and New York: Routledge, 2015.

Bordessa, Ronald. "The City in Canadian Literature: Realist and Symbolic Interpretation." The Canadian Geographer/Le Géographe Canadien, vol. 32, no. 3, 1988, pp. 272-274.

Bouvet, Rachel, and Stephanie Posthumus. "Eco- and GeoApproaches in French and Francophone Literary Studies." Handbook of Ecocriticism and Cultural Ecology, edited by Hubert Zapf, De Gruyter, 2016, pp. 385-412.

Brosseau, Marc. Des romans-géographes: le roman et la connaissance géographique des lieux, Thése de doctorat en Geographie, Soutenue en 1992 à Paris 4 (Of novelsgeographers: the novel and the geographical knowledge of places.

Brosseau, Marc. "Geography's Literature." Progress in Human Geography, vol. 18, no. 3, Sept. 1994, pp. 333-353., doi:10.1177/030913259401800304.

Brosseau, Marc. "Literature." International Encyclopaedia of Human Geography, edited by Rob Kitchin and Nigel Thrift, vol. 6, Elsevier, 2009, pp. 212-218., doi: 10.1016/B978-0080449104.00968-8

Buell, Lawrence. Writing for an Endangered World: Literature, Culture, and Environment in the U.S. and Beyond. Harvard University Press, 2001.

Buell, Lawrence. The Future of Environmental Criticism: Environmental Crisis and Literary Imagination. Blackwell, 2005. 
Carter, Erica, et al. "Introduction." Space and Place: Theories of Identity and Location, edited by Erica Carter et al., Lawrence and Wishart, 1993, pp. vii-xv.

Coquard, Sebastian, "Cartography 1: Mapping Narrative Cartography," Progress in Human Geography 37.1 (November 2011): 135-144.

Cosgrove, Denis. "Introduction: Mapping Meaning," Mappings, edited by Denis Cosgrove, Reaktion Books, 1999, 1-23.

Cosgrove, Denis. Geography and Vision: Seeing, Imagining and Representing the World. I.B. Tauris, 2008.

Doležel Lubomír. Heterocosmica: Fiction and Possible Worlds. Johns Hopkins Univ. Press, 1998.

Dósa, Attila. "Kenneth White: A Strategist of Mutation." Beyond Identity: New Horizons in Modern Scottish Poetry 13 Rodopi, 2009, 259-279. SCROLL: Scottish Cultural Review of Language and Literature.

Eilers, Perthenia. Creating an Environmental Conscience: Revelation and Depiction as Rhetorical Strategies in Rachel Carson's Silent Spring. University of Wisconsin-- Madison, 1994.

Glotfelty, Cheryll, and Harold Fromm, eds. The Ecocriticism Reader: Landmarks in Literary Ecology, University of Georgia Press, 1996.

Glotfelty, Cheryll, "Introduction: Literary Studies in an Age of Environmental Crisis," Glotfelty and Fromm, eds., xv-xxxvii.

Haraway, Donna J. Primate Visions: Gender, Race, and Nature in the World of Modern Science. Routledge, 1990.

Kim, Lawrence Young. Homer between History and Fiction in Imperial Greek Literature. Cambridge University Press, 1970, 2010.

Konończuk, Elżbieta. "In the Meanders of Geopoetics." Teksty Drugie, vol. 1, no. 9, 2016, pp. 152-164., doi:10.18318/td.2016.en.1.9.

McManus, Tony. The Radical Field: Kenneth White and Geopoetics. Sandstone Press, 2007.

Meeker, Joseph W. The Comedy of Survival; Studies in Literary Ecology. Scribner, 1972. 
The Map and the Text: The Geo-Literary Spatial Encounters

Mitchell, Peta, and Jane Stadler. "Redrawing the Map: An Interdisciplinary Geocritical Approach to Australian Cultural Narratives." Geocritical Explorations: Space, Place, and Mapping in Literary and Cultural Studies, edited by Robert T. Tally, Palgrave Macmillan, 2011, pp. 47-62.

Moretti, Franco. Atlas of the European Novel 1800-1900. Verso, 1998. Pavel, Thomas G. Fictional Worlds. Harvard University Press, 1986.

Piatti, Barbara, and Lorenz Hurni. "Editorial: Cartographies of Fictional Worlds." The Cartographic Journal, vol. 48, no. 4, Nov. 2011, pp. 218-223., doi:10.1179/174327711X13190991350051.

Piatti, Barbara, et al. "Mapping Literature: Towards a Geography of Fiction." Cartography and Art, edited by William Cartwright et al., Springer-Verlag, 2009, pp. 177-192. Lecture Notes in Geoinformation and Cartography.

Pocock, Douglas C. D. "Introduction: Imaginative Literature and the Geographer," Humanistic Geography and Literature: Essays on the Experience of Place, edited by Douglas C. D. Pocock, Social and Cultural Geography, Routledge Literary Editions, 2014, 919.

Prieto, Eric. "Geocriticism Meets Ecocriticism: Bertrand Westphal and Environmental Thinking." Ecocriticism and Geocriticism: Overlapping Territories in Environmental and Spatial Literary Studies, edited by Robert T. Tally and Christine M. Battista, Palgrave Macmillan, 2016, pp. 19-36. Geocriticism and Spatial Literary Studies.

Riquet, Johannes. "Framing the Debate: Spatial Modernities, Travelling Narratives." Spatial Modernities: Geography, Narrative, Imaginaries, edited by Johannes Riquet and Elizabeth Kollmann, Routledge, 2018, pp. 1-24.

Rueckert, William. "Literature and Ecology: An Experiment in Ecocriticism." Iowa Review, vol. 9, no. 1, 1978, pp. 71-86.

Ryan, Marie-Laure. "Narrative Cartography: Towards a Visual Narratology," What Is Narratology? Questions and Answers Regarding the Status of a Theory, edited by Tom Kindt and Hans-Harald Mūller, Berlin and New York: Walter de Gruyter, 2003, 222-264. 
Ryan, Marie-Laure. "Possible Worlds." Handbook of Narratology, edited by Peter Hühn et al., 2nd ed., vol. 1, De Gruyter, 2014, pp. 726-742.

Siewers, Alfred K. "Ecocriticism." A Dictionary of Cultural and Critical Theory, Edited by Michael Payne and Jessica Rae Barbera, $2^{\text {nd }}$ ed., Blackwell Publishing, 2010, pp. 205-210.

Smith, Jos. New Nature Writing: Rethinking the Literature of Place. Bloomsbury Academic, 2017.

Slovic, Scott. "The Third Wave of Ecocriticism: North American Reflections on the Current Phase of the Discipline." Ecozon@: European Journal of Literature, Culture and Environment; vol. 1, no. 1, 2010, pp. 4-10. New Ecocritical Perspectives: European and Transnational Ecocriticism, ecozona.eu/article/view/312/283.

Snow, Charles. Two Cultures. Cambridge University Press, 1998.

Soja, Edward W. Postmetropolis: Critical Studies of Cities and Regions. Blackwell, 2000.

Tally, Robert T. Jr. "Series Editor's Preface," Ecocriticism and Geocriticism: Overlapping Territories in Environmental and Spatial Literary Studies, edited by Robert T. Tally Jr. and Christine M. Battista, London: Palgrave Macmillan, 2016, ix-x.

Tally, Robert T. Jr. Spatiality. Routledge, 2013.

Tošić, Jelica. "Ecocriticism: Interdisciplinary Study of Literature and Environment." Working and Living Environmental Protection, vol. 3, no. 1, 2006, pp. 43-50.

Tuan, Yi-Fu. "Geography, Phenomenology, and the Study of Human Nature." The Canadian Geographer/Le Géographe Canadien, vol. 15, no. 3, 1971, pp. 181-192., doi:10.1111/j.15410064.1971.tb00156.x.

Tuan, Yi-Fu. "Humanistic Geography." Annals of the Association of American Geographers 66.2, June 1976, 266-76., doi:10.1111/j.1467-8306.1976.tb01089.x.

Tuan, Yi-Fu. "Literature and Geography: Implications for Geographical Research." Humanistic Geography: Prospects and Problems, edited by David Ley and Marwyn S. Samuels, 15, Social and Cultural Geography, Routledge Literary Editions, 2014, 194-206. 
The Map and the Text: The Geo-Literary Spatial Encounters

Westphal, Bertrand. Geocriticism: Real and Fictional Spaces. Translated by Robert T. Tally Jr., Palgrave Macmillan, 2011.

White, Kenneth. Geopoetics: Place, Culture, World. Alba, 2003.

White, Kenneth. The Wanderer and His Charts: Exploring the Fields of Vagrant Thought and Vagabond Beauty, Edinburgh: Polygon, 2004.

White, Kenneth. On the Atlantic Edge: a Geopoetics Project. Dingwall: Sandstone Press, 2006.

White, Kenneth. "Geopoetics." Kenneth White - La Géopétique, 2008, www.kennethwhite.org/geopoetique/.

White, Kenneth. Ideas of Order at Cape Wrath: The Tentative Contours of a Political, Intellectual and Cultural Paradigm. Research Institute of Irish and Scottish Studies, University of Aberdeen, 2013.

White, Kenneth, and Attila Dósa. "A Strategist of Mutation." Beyond Identity: New Horizons in Modern Scottish Poetry, vol. 13, Rodopi, 2009, pp. 259-279. SCROLL: Scottish Cultural Review of Language and Literature. 


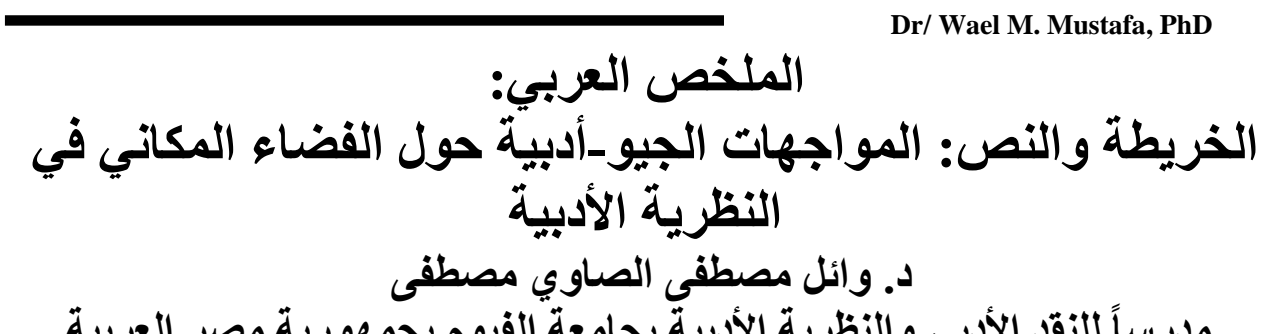

مدرساً للنقة الأدبي والنظرية الأدبية بجامعة الفيوم بجمهورية مصر العربية

لطالما قدم كلا من علم الجغر افيا وفن الأدب إضاءات تنبر بعضهها البعض؛ إلإ

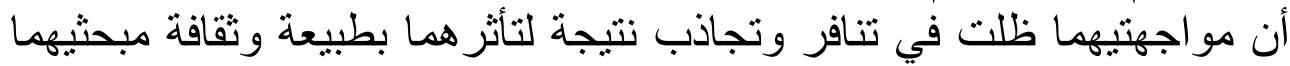

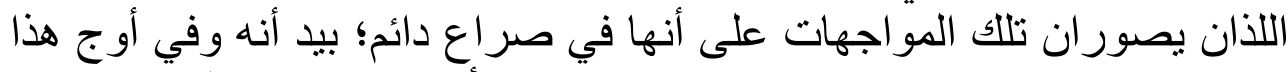

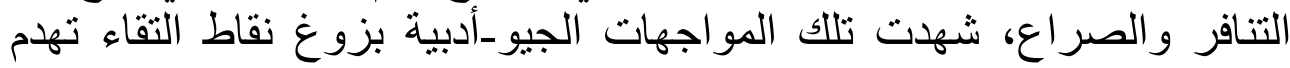

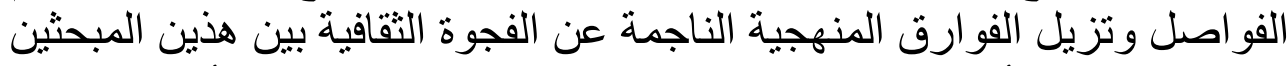

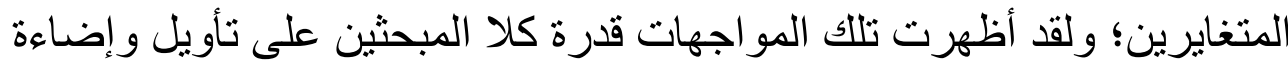

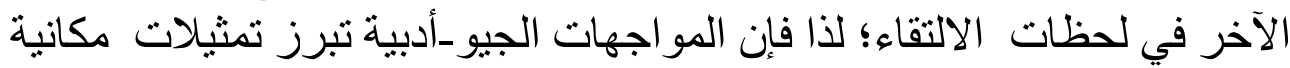

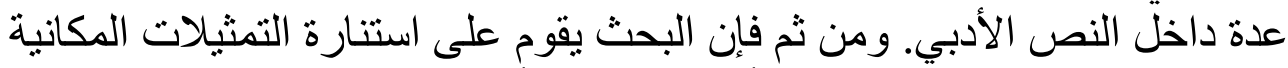

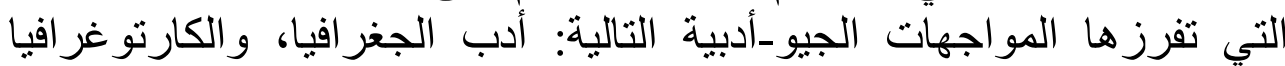

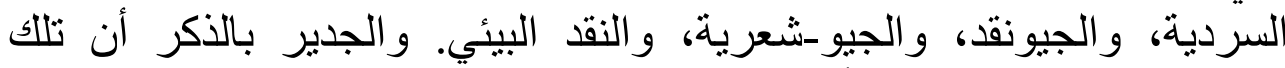

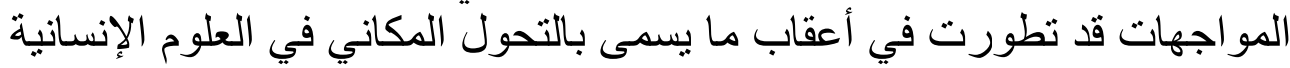

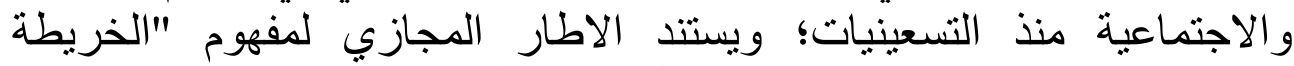

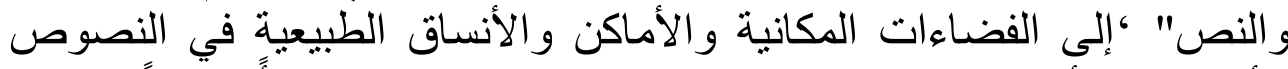

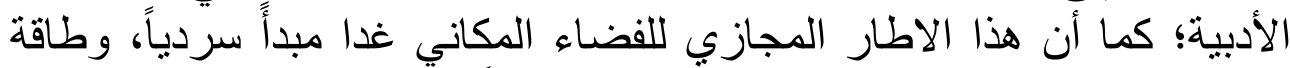

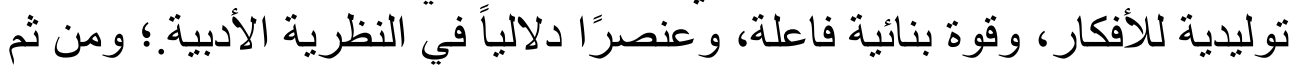

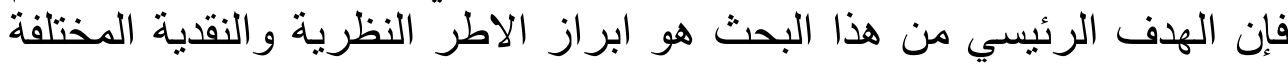

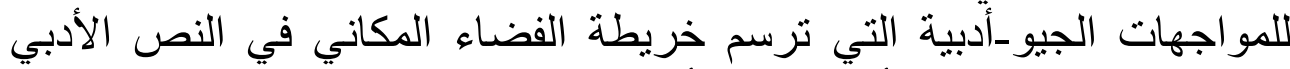

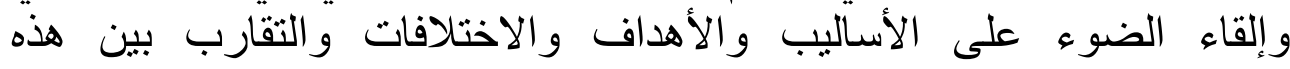
المواجهات البينية. - الئه

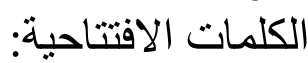
التحول المكاني ـ النظرية الأدبية ـ المواجهات الجيو _أدبية ـ الدر اسات البينية

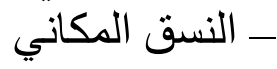

